\title{
Cord blood bank plans evolve with "glacial speed"
}

$\infty \quad$ See related editorial, page 1279

$\longrightarrow$ anada's status as an outlier nation that relies almost entirely on other developed countries to provide life-saving umbilical cord blood stem cells for transplants may be about to change.

"Certainly Canada is lagging behind. We are one of the few G20 nations without a public cord blood bank," says Sue Smith, executive director of OneMatch Stem Cell and Marrow Network, the Canadian Blood Services division responsible for finding matches from cord blood, bone marrow or peripheral blood stem cells for patients who need to "regrow" blood but lack a related, matched donor.

Provincial and territorial deputy ministers of health were scheduled to decide in mid-June whether to support a jointly financed first phase of a Canadian public cord blood bank to store a domestic supply.

A positive decision would come none too soon for the many transplant surgeons and physicians who are frustrated and discouraged at what one political insider has labelled the "glacial speed" of the bid to create a public cord blood bank in Canada. In 2002, deputy ministers asked Canadian Blood Services to investigate the need for a public bank. It reported back that a need did not yet exist. The deputies repeated the request in 2005, and 2 years later, Canadian Blood Services delivered a 48-page set of recommendations for establishing a public bank. The deputy ministers agreed to fund a detailed business plan which, nearly 2 years later, is expected to carry a phase- 1 price tag that well exceeds a 2007 costestimate of \$4.5 million.

"The development with CBS [Canadian Blood Services] has been very slow, and it has been difficult to keep community interest up," says Dr. Donna Wall, director of the Manitoba Blood and Marrow Transplant Program.

"We are so far behind," laments Dr. Lothar Huebsch, an Ottawa, Ontario, transplant surgeon and former president of the Canadian Bone and Marrow Transplant Group. In the

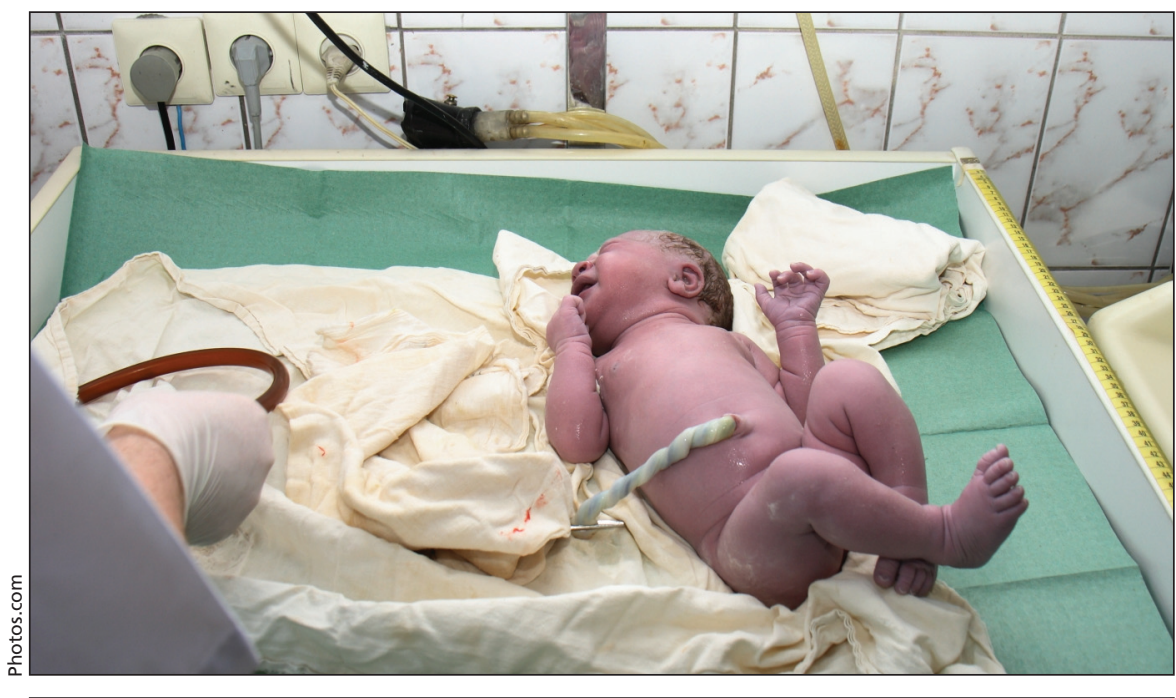

The first public cord blood bank was established at the New York Blood Center in New York City, New York, in 1992.

United States, for example, Congress allocated US\$12 million in 2005 to establish a national inventory and increase its supply of publicly available cord blood.

"I've heard some doctors say why not just buy the cord blood, like it is too hard to set up a bank," says Locksley McGann, professor of laboratory medicine and pathology at the University of Alberta, in Edmonton, Alta., who years ago established a human tissue bank at the university. "That is the kind of thinking that keeps us as a colony."

A national bank would not be expensive and "it meets all the feel-good criteria," says Huebsch, who maintains lives will be saved if more, and more genetically diverse, cord blood is available for transplant into unrelated individuals.

Huebsch and others maintain that a Canadian bank would be uniquely valuable because of the genetic heterogeneity of the population, which is not reflected in bone marrow registries since the vast majority of donors are of Caucasian and European background.

Clinical practice and research around the use of hematopoietic progenitor cells from cord blood have been advancing quickly: cords are now used in the vast majority of transplants in children and, increasingly, in adults.

"As a pediatric transplanter, about $80 \%$ of my unrelated donor transplants are done using cord blood as the donor source," says Wall, who returned to Canada in 2008, after 20 years in the US, during which she was instrumental in establishing the public St. Louis Cord Blood Bank in St. Louis, Missouri, in 1996.

Cord blood carries fewer viruses than stems cells from older donors, there is less graft versus host disease and "very often the tempo of the disease in children is so rapid that there is not time to do an adult unrelated search and procurement," Wall says. (Cord blood is frozen and readily available whereas a medical procedure is necessary to extract marrow or peripheral blood from living donors.)

In recent years, there has also been an increase, internationally, in the number of double cord transplants in adults (double cords are typically required to have sufficient volume in order to renew the blood of adults). As a consequence, Wall says it is now routine for her transplant unit to search for cord matches for adults.

While Canadian surgeons have been slower to adopt the use of cord blood for transplants than some of their US and European colleagues, their pace is picking up. In 2008/09, 88 Canadian patients - up from 73 for the same period a year earlier — were transplanted with cord blood purchased from foreign pub- 
lic banks at a cost of between $\$ 32000$ and $\$ 35000$ a unit, Smith says.

Worldwide, 2743 cord blood products (up from about 1800 in 2006) were shipped from 107 public cord blood banks, according to 2007 World Marrow Donor Association figures. About $40 \%$ of those units were shipped across international borders.

Canada's Stem Cell Network has endorsed the creation of a national cord blood collection initiative, provided (among other criteria) that it is operated by a nonprofit entity and given longterm funding by federal, provincial and territorial governments. Between $45 \%$ and $85 \%$ of cord blood collected is not appropriate for storage, usually because there is insufficient volume or the unit has been contaminated. These "rejected" cord blood units would be made available to Canadian researchers after appropriate ethics review and with donor consent.

"This is something that is otherwise medical waste that can truly save lives," says Smith. "The beauty of it is that it's a joy, joy situation — to give birth and to be able to donate cord to save someone's life."

Quebec, which is not a member of Canadian Blood Services, established a government-funded bank at HémaQuébec in 2004. The Quebec bank has been building inventory and is just beginning to make its cord blood available on worldwide registries.

It is proposed that the national bank be run by Canadian Blood Services. An outstanding issue has been incorporating cord blood collected at a public nonprofit bank, not funded by government, in Alberta that was established in 1996 by Dr. John Akabutu, professor of pediatrics at the University of Alberta. While his bank has collected thousands of donated cord blood units, it has been plagued with uncertain funding, and most of its cord blood has not yet been human leukocyte antigen typed for use. - Ann Silversides, CMAJ

\section{DOI:10.1503/cmaj.090971}

Published online at www.cmaj.ca on Jun. 10. A related story on the compatibility of private and public cord blood banks is published at www.cmaj.ca.

\section{Briefly}

Euro-mapping: Countries oftbranded as tourist sex destinations in Europe are net exporters of the HIV virus, according to a European research team, (www.retrovirology.com /content/pdf/1742-4690-6-49.pdf). The team tracked the movement of the virus through 17 European countries and found that Greece, Portugal, Serbia and Spain are big HIV exporters. Austria, Belgium and Luxembourg are largely importers.

Space doctor: Dr. David Saint-Jacques, clinical faculty lecturer at McGill University in Montréal, Quebec, has been chosen as one of Canada's newest astro-

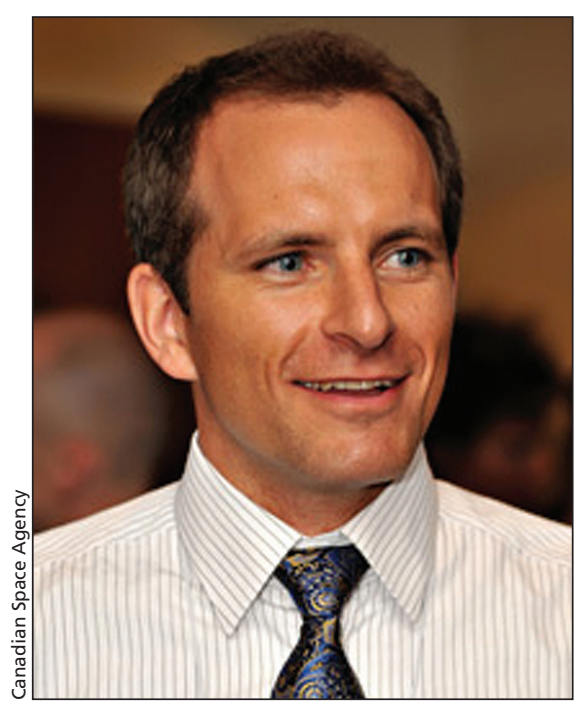

Dr. David Saint-Jacques nauts by the Canadian Space Agency. Saint-Jacques, a practising physician at the Innulitsivik Health Centre in Purvirnituq, northern Quebec, was born in Québec City, Que. He earned his MD in 2005 from the Université Laval in Québec City, Que. He also holds a PhD in astrophysics from Cambridge University in Cambridge, England.

Walkabout: Australian Health and Ageing Minister Nicola Roxon has unveiled an A \$134.4 million rural health package that will grant $\mathrm{A} \$ 15000$ to doctors who relocate from a major city to a regional centre and $\mathrm{A} \$ 120000$ to those relocating to very remote areas. Doctors now practising in remote areas will see retention incentives bolstered to $\mathrm{A} \$ 47000$ per year from $\mathrm{A} \$ 25000$ per year.

Manufacturing practices: Health Canada has unveiled new guidelines for good manufacturing practices for pharmaceutical, radiopharmaceutical, biological, and veterinary drugs. The department stresses, though, that the guidelines are nonbinding. "Alternative means of complying with these Regulations can be considered with the appropriate scientific justification. Different approaches may be called for as new technologies emerge" (www.hc-sc.gc .ca/dhp-mps/alt_formats/hpfb-dgpsa/pdf /compli-conform/gmp-bfp/docs/gui-0001 -eng.pdf). — Wayne Kondro, CMAJ

DOI:10.1503/cmaj.090929

\section{More news at www.cmaj.ca}

Residency match: The bulk of unfilled residency positions from the annual CARMS match are in Quebec. - Ann Silversides, CMAJ

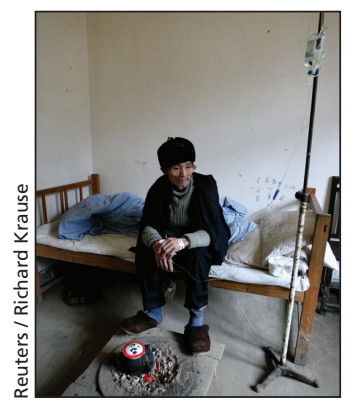

Great leaps: China unveils its long awaited health care reform blueprint. - Katie Lewis, Beijing, China

Blood banks: Proponents of the proposed public cord blood bank contend they won't compete with private banks because their material would target genetic types. - Ann Silversides, CMAJ

DOI:10.1503/cmaj.090974

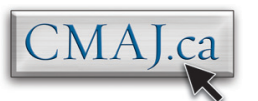

